\title{
The Relationship between Teachers and School Professional Staff's Retention and Managerial Styles
}

\author{
Luis Miguel Dos Santos \\ Woosong Language Institute, Woosong University, Daejeon, South Korea. \\ Email: luismigueldossantos@yahoo.com
}

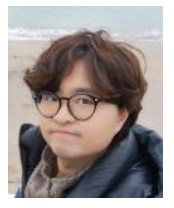

\begin{abstract}
The retention of teachers and school professional staff is a challenge for the development and management of schools, particularly for international schools with difficulties in recruiting qualified teachers and school professional staff from overseas. However, only a few research projects have focused on how administrative styles influence the turnover of international school teachers and school professional staff. The researcher collected data from two semi-structured interview sessions with 51 international school teachers who have taught at an international school for more than a decade in one of two metropolitan districts in mainland China. This project aims, through the lens of Social Cognitive Career Theory, to understand why international school teachers and school professional staff decide to stay in a particular international school for their teaching career development. The participants indicated "acknowledgement from upper leadership", "classroom/workplace authorities", and "well-established facilities" to explain their current occupation as experienced international school teachers. The findings also outline potential solutions which could control the high turnover rate in international schools and local schools in the East Asian regions.
\end{abstract}

Keywords: Burnout, Chinese international school, International school, Retention, School human resource, School leadership, Social cognitive career, Turnover.

Citation | Luis Miguel Dos Santos (2020). The Relationship between Teachers and School Professional Staff's Retention and Managerial Styles. Journal of Education and e-Learning Research, $7(1): 42-48$

History:

History:

November 2019

Revised: 12 December 2019

Accepted: 22 January 2020

Published: 4 March 2020

Licensed: This work is licensed under a Creative Commons

Attribution 3.0 License (c)

Publisher: Asian Online Journal Publishing Group
Funding: This study received no specific financial support.

Competing Interests: The author declares that there are no conflicts of interests regarding the publication of this paper.

Transparency: The author confirms that the manuscript is an honest, accurate, and transparent account of the study was reported; that no vital features of the study have been omitted; and that any discrepancies from the study as planned have been explained.
fital features of the study have been omited;

Ethical: This study follows all ethical practices during writing.

\section{Contents}

1. Introduction .

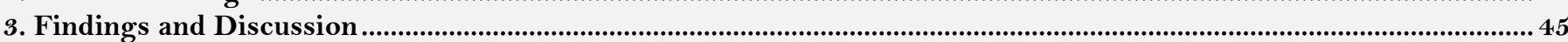

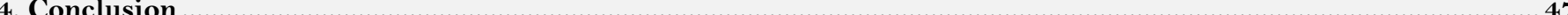

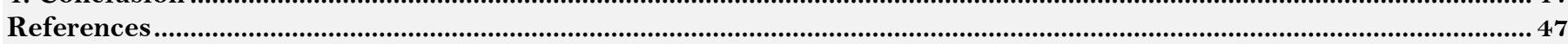




\section{Contribution of this paper to the literature}

This paper contributes to the field of teachers' professional development, school human resource management, international schooling, and teacher turnover rate.

\section{Introduction}

Teachers and professional school staff always face challenges, stresses and even burnouts due to the complexities of their tasks and responsibilities (Dos Santos, 2019c). Although teaching and educational services are two of the most meaningful career developments and pathways for individuals to invest in, their countries, school districts and communities continue to face a human resource shortage and high staff turnover (Dos Santos, 2016).

For more than a century, the fields of science teaching and learning have been under extreme pressure to train and prepare skilled professionals, regardless of geographic regions. P-12 science teaching is a significant investment for individuals, schools, communities and countries since science subject material could continue to contribute to the country's development (Zeidler, 2016). Although a large number of faculties of education at the college and university-level always attract many applicants and students for their teacher training programmes (e.g. Bachelor of Education, Postgraduate Certificate in Education and Master of Arts in Teaching), the gaps between qualified teachers being recruited and retained are still significant. Therefore, the methods of hiring newly qualified teachers has changed in the past few decades, particularly in the fields of Science, Technology, Engineering and Mathematics (STEM) subject matters (Guarino, Santibanez, \& Daley, 2006).

Due to a continual human resource shortage in the field of school human resource management, a large number of local schools, private schools, international schools, charter schools, private academies, affiliate educational providers, vocational training centres, school districts, Department of Education and Department of Workforce Management have developed various schemes and programmes to attract potential teachers, school professional staff, administrators, leaders, principals and even clerks internationally. One of these schemes is to attract careerchanging or second-career professionals to fill career opportunities (Chambers, 2002). Such potential applicants may include professionals who would like to switch to teaching after having previous professional and industrial experience in the field. These are known as career-changing teachers or second-career teachers (Dos Santos, 2019a).

\subsection{Purpose of this Study}

Many schools and school districts are facing the human resource challenge of teachers and school professional staff recruitment. There are three points of exploration listed for this study. Firstly, the turnover rate is significantly high for both experienced and junior-level teachers and school professional staff. This turnover is a significant issue in the field of international schooling, particularly since it will negatively impact the learning outcomes of students, along with the sustainable development of the schools (Hayden, 2006). The departure of teachers and school professional staff impacts two elements (Odland \& Ruzicka, 2009). First, international school human resources departments need to spend their budgets on recruiting qualified teachers and school professional staff both locally and from overseas. This spending could be high as it includes visa fees, compensation, housing allowance, flight reimbursement, reimbursement, children's tuition fees, insurance and travel allowance among others. Second, the learning outcomes of the student could be impacted as their accumulated assessments are interrupted. In order to control the high turnover, gaining understanding from experienced teachers who have had more than ten years of teaching service at an international school is essential.

Secondly, several research studies (Ingersoll, 2001; Odland \& Ruzicka, 2009; Ronfeldt, Loeb, \& Wyckoff, 2013) have focused on teacher retention problems by concentrating on a particular city or zone which could reflect the overall issues and situations in a large-sized region. Also, there are only a few research studies concerned with retention at international school-level where teachers and school professional staff are often from a different part of the world with various cultural backgrounds (Hardman, 2001). International school teaching is one of the best known career developments for both junior and senior-level teachers, since living in a new cultural environment is unique (Chandler, 2010). However, teaching and living in an unfamiliar environment is not an easy step, particularly for teachers without any overseas experience (Hardman, 2001; Hayden \& Thompson, 2008). Based on these factors, the turnover at international schools is found to be much higher than at local schools (Ingersoll, 2001; Ingersoll, 2003; Ingersoll. \& Smith, 2003).

Thirdly, science education has historical roots in the humanities. Although science subjects and establishments may not be able to read and view, the subjects of physics, chemistry, biology, mathematics and engineering surround us in contemporary human society, such as food science, architectural principles, chemical medicine, transportation and so on. Therefore, the Science, Technology, Engineering and Mathematics (STEM) education curriculum and instructional plans engage various types of essential skills that P-12 students will need to handle to survive in society today (Al Salami, Makela, \& de Miranda, 2017; Reinhold, Holzberger, \& Seidel, 2018). Although STEM teachers and school professional staff who graduated directly from one of the qualifying programmes from the faculty of education at college or university-level are qualified to provide standardised education and instruction to P-12 students, many of them do not have either professional or industrial experience outside the traditional classroom environment. These teachers and school professional staff may not understand the industrial expectations that potential employers demand in the business environment. As a result, many employers complain that graduates at school level do not understand how to apply textbook knowledge and theories in the workplace and industrial scenarios (Bubbar, Dimopolous, Gaetz, Wild, \& McWilliam, 2017). Therefore, attracting teachers and school professional staff with professional and industrial experience highly increase the teaching and learning experiences for both in-service teachers and students in the contemporary classroom environment.

For this current research study, the researcher explored the reasons why workforce with industrial experience in the field of one of the STEM professions decided to complete a teacher's professional qualification programme or a teacher's qualifying initial programme, known as the Postgraduate Diploma in Education (PGDE), Postgraduate 
Certificate in Education (PGCE) or Master of Arts in Teaching (MAT), and switch their career development and direction to international school secondary STEM teaching at one of the international schools in mainland China. Additionally, the current study aims to understand the reasons why international school teachers and school professional staff decided to stay at one of the overseas international schools for their teaching career development in two urban Chinese metropolitans (i.e. Beijing and Shanghai). As a result, two research questions were created to lead this research study as follows:

- Why do international school teachers and school professional staff decide to stay and invest their career development at one of the international schools in mainland China?

- Why do international school teachers and school professional staff decide to switch their professional and industrial positions to secondary Science, Technology, Engineering, and Mathematics (STEM) teaching at one of the international schools in mainland China?

Career development and selection is a complex issue for exploration. In order to gain a holistic picture of individual career selection and development, an appropriate theoretical framework is important. The Social Cognitive Career Theory (SCCT) served as the theoretical framework to explore individual decisions which could be influenced by interests, choice of goals and performance \& attainment (Lent, Brown, \& Hackett, 1994).

\section{Research Design}

\subsection{Participants}

First, a brief background of the participants. This study explored 51 international school teachers and school professional staff, made up of 22 American, 17 British, four Australian, four New Zealander, two Canadian and two South African, who have been providing teaching and educational services at one of the international schools either in Beijing or Shanghai, China for more than a decade. The participants did not need to have stayed at the same international school for ten years, but must have provided teaching and educational services in the international school environment in mainland China for more than ten years.

Second, the positions of the participants. The participants must have been qualified to provide teaching and educational services in one of the secondary STEM subject matters at one of the international schools in mainland China. The educational positions included but are not limited to, school teachers, lab technicians, science specialists, health promotion specialists and nurses.

Third, the locations of the participants. 30 of the participants were based in Beijing, while 21 were based in Shanghai. Beijing and Shanghai are two of the largest metropolitans with significant populations, foreign organisations, international trading centres, expat populations and political and commercial backgrounds in mainland China. Therefore, exploring the issues and situations in these two metropolitans can provide us with an overall and holistic picture of the contemporary situations and issues in mainland China.

Fourth, all the participants had to match the following criteria in order to be invited:

- Have completed at least a bachelor's degree in the field of STEM subject matters.

- Have completed a teacher's professional qualification programme or a teachers' qualifying initial programme, i.e. PGDE, PGCE or MAT.

- Have worked in the professional and industrial field outside teaching before joining the teaching and educational professions at the international school environment in mainland China.

- Have at least ten years of international school experience after completing the teacher's professional qualification programme or a teachers' qualifying initial programme.

- Have no current plan to leave the teaching and educational profession at one of the international school environments in mainland China for the coming academic year at the time of writing (e.g. as of Summer 2019).

\subsection{Data Collection}

Two semi-structured interview sessions were hosted to collect meaningful data from the participants (Seidman, 2013). For each interview session, the researcher aimed to capture data and sharing for three stages, focusing on:

- Why do international school teachers and school professional staff decide to stay and invest their career development at one of the international schools in mainland China?

- Why do international school teachers and school professional staff decide to switch their professional and industrial positions to secondary STEM teaching at one of the international schools in mainland China?

The general inductive approach (Thomas, 2006) was used to analyse the interview data. During the first interview session, each participant was asked why they decided to stay and invest their career development at one of the international schools in mainland China. During the second interview session, each participant was asked why they decided to switch their professional and industrial positions to secondary STEM teaching at one of the international schools in mainland China. Both interview sessions were hosted for 105-135 minutes due to the rich and meaningful life stories being shared and collected.

Although the study did not follow the narrative research methodology (Clandnin \& Connelly, 2000; Connell \& Clandinia, 1990) with a small population and sample, the researcher tended to collect rich and meaningful life stories and sharing of personal experiences in order to increase the research background and in-depth understanding of the participants and the answers to the research questions. Therefore, the researcher employed a number of in-depth protocol and interview questions (Creswell, 2012; Merriam, 2009; Tang \& Dos Santos, 2017) in order to gain holistic and colourful supporting data and understanding from the participants.

\subsection{Data Analysis}

Themes and categories were employed after the data collection procedure. The general inductive approach was used for this study. The general inductive approach (Thomas, 2006) allows the researcher to understand the real- 
life stories and in-depth sharing. First, the researcher followed the general inductive approach to narrow large transcripts down to first-level themes by using open-coding strategy from the idea of a grounded theory approach (Strauss \& Corbin, 1990). A number of researchers advocated that qualitative data collectors should re-read the written transcripts multiple times and categorise the grouping patterns (Creswell, 2012).

Second, after the researcher had narrowed the data information down into first-level themes, the overall patterns and themes which emerged were multiple. Therefore, the researcher needed to employ the axial-coding strategy to further narrow first-level themes down into second-level themes for reporting. As a result, three themes were categorised for findings and discussion (Creswell, 2012; Merriam, 2009).

\subsection{Human Subject Protections}

The human subject protections were the most important factor in this study. Without any human subject protection procedures, no participants would present any real life stories or in-depth sharing to the researcher. Therefore, the researcher made all efforts to protect the identities of all participants by masking their names. Participant identifications were all masked by assigned pseudonyms. Only the subjects (e.g. Biology), position (e.g. teacher, lab technician), and current teaching city location (e.g. Beijing) were reported (Creswell, 2012; Merriam, 2009).

Once the researcher had completed the analysis, findings and discussion procedures, the researcher deleted and destroyed all signed documents, oral and written transcripts and records, data information, contact information, personal background and related documents of this study. The above materials were all stored in a passwordprotected cabinet. Only the researcher had the right of access to the cabinet (Creswell, 2012; Merriam, 2009).

\section{Findings and Discussion}

During both interview sessions, all participants were given and responded to the same interview questions. Although all of the participants may have shared similar educational, industrial and personal backgrounds during their early adulthood, their personal living standards, real-life stories, and life experiences were not the same. All the participants were from an English-speaking country. Based on the Social Cognitive Career Theory (Lent. et al., 2001; Lent.. \& Brown, 1996; Lent..., Brown, \& Hackett, 2000) interests, choice of goals and performance and attainment are three of the key elements which influence individual career choices and development (Bandura, 1995; Bandura., 1989). Some previous studies (Dos Santos, 2019d) indicate that international school teachers and school professional staff usually care about the external environmental factors and choice of goals due to social and cultural differences in the hosted countries and regions (Hayden \& Thompson, 2008). A study explored a group of international school teachers who currently or had previously taught at one of the international schools in the Oceanian country. The study indicated that the remote location of the Oceanian country usually limited the socialnetworking and connections of these groups of international school teachers and school professional staff. For example, some participants believed they could not leave the country during leisure time. Therefore, no matter how meaningful their positions were, a group of people decided to leave the Oceanian country (Dos Santos, 2019d).

In this current study, 51 international school teachers and school professional staff shared real-life stories and opinions on administrative style and the teaching and learning experiences are significant factors for their retention. Most of the participants saw a high level of expectation from schools, parents, students and the turnover rates of their co-workers, they believed:

- Acknowledgement from upper leadership.

- Classroom/workplace authorities.

- Well-established facilities.

were three of the most important factors for staying and investing in their career development as secondary STEM teachers and school professional staff at one of the international schools in mainland China. As a result, the researcher categorised the key factors as the themes for reporting.

\subsection{Acknowledgement from the Upper Leadership}

Unlike traditional teachers who graduated from university directly via the Bachelor of Education programme, all of the participants in this study were second-career or career switching teachers and school professional staff with professional and industrial experience outside the teaching and educational sector. As these participants had worked in the 'for-profit' business environment from the lowest level of the organisational structure, they usually understood organisational hierarchy and levelling management and operation. In other words, these participants had extensive experience in how to manage workplace conflicts, industrial relationships, co-worker relationships and time management in the 'for-profit' business environment.

\subsubsection{The Administrators Usually Acknowledged their Hardworking}

All the participants expressed that their school administrators, leaders and supervisors usually acknowledged their work, activities, after-school programmes, school club activities, meetings and teachers' professional development sharing. Besides the responsibilities outside their contract, the participants liked to invest some personal time beyond their normal school-office hours. All the participants expressed that they would like to invest extra forces and efforts as they would like to contribute their energy and time to the schools, the children, the students and the communities. Such offers always received positive acknowledgement which they had never received in the 'for-profit' business environment. One said, 'in business companies, overtime responsibilities and tasks are required with no appreciation...in school, I can receive positive appreciation and student effort as a result of that investment...I enjoy these rewards..." (Teacher \#3, Biology, Beijing). Many teachers believed that appreciation from both school leaders and students always encouraged them to continue their teaching career developments at one of the international schools in mainland China. Many others also echoed that appreciation from school leaders and students continued to encourage their teaching career. For example, a participant shared a 
story about encouragement from his students. He said "I hosted a music piano club after school every Tuesday for interested parties...many of my students learned music knowledge with me for more than nine years...when they went to performances and music events, they always invited me and said a thank you message to me from the stage...(Teacher \#19, Music, Beijing)

Besides the after-school activities, many participants expressed the appreciation of their school leaders and supervisors. First, many teachers explained that the school leaders and administrators always hosted seasonal parties and gatherings to which they invited teachers and school professional staff's family members to join in and celebrate the hard work. Many of them advocated that such gatherings and parties served as tokens of appreciation and human resource management. For example, many advocated that the employee's engagement and morale are very important for expats and international school teachers and school professional staff who may not have families or friends in the host cities and countries. They said, "my school is my family and my home...my school knows how to engage all teachers and staff together as a family...we are not alone in China...this school knows how to show appreciation to all of us..." (Teacher \#1, Chemistry, Shanghai).

In short, the participants expressed that the freedom of hosting clubs and activities always encouraged them to continue their career development at one of the international schools in mainland China. Most of the teachers expressed the word "freedom" during the interview sessions as this was one of the most important factors for their career development. Besides, the appreciation from administrators and school leaders also encouraged their career decisions. In fact, many said that the school environment and non-profit organisational background provided them with a better working environment. More importantly, a positive school teaching and learning environment with a high level of morale and engagement also increased their retention rates.

\subsection{Classroom/Workplace Authorities}

Teaching is an isolated career since teachers always work alone with their students (Weiner, 2012; Weiner \& Jerome, 2016). Although teachers and school professional staff are encouraged to share their teaching ideas, materials, strategies and methodologies to other fellows and co-workers, most of the teachers continue with their own ways of teaching since the progress of each class is not the same. As a result, some junior-level teachers and school professional staff decided to leave the teaching and educational professions due to the isolating and lonely nature of the career (Dos Santos, 2019d). In this study, many of the participants expressed their appreciation of teaching and educating in an isolated environment due to their personalities and behaviours. For example, when the researcher asked about the preferred method of working (e.g. alone or in a group), all the participants expressed that the isolated working environment was their only preference. As one said, "who wants to work in a group with more than ten people...one is not available, he is not in town, she has families, they have children...in my classroom, I can work on my own without any cooperation...” (Teacher \#12, French, Shanghai).

\subsubsection{Flexibilities of Materials / Tasks / Responsibilities Designs}

Besides the freedom of classroom management and arrangements, many participants advocated that they have the flexibility to design their teaching and learning materials, tasks, homework, activities and responsibilities based directly on the needs of their students and classrooms (Brouwers \& Tomic, 2000; Dicke, Elling, Schmeck, \& Leutner, 2015). All the participants advocated that they could arrange their own teaching and learning materials based on their own decisions. This could not have happened during their previous career development in the business environment. For example, a physics teacher shared his story about the unique arrangement of his $11^{\text {th }}$ graders. He said, "I always develop some activities and outdoor learning programmes based on the textbook materials...If I had continued to work in industry, I would still need to listen to my supervisors and gain the approval of any further steps... as a teacher, I can do the proper steps for my students... "(Teacher \#27, Physics, Beijing)".

Some other teachers and school professional staff shared that their school does not have any particular standards or guidelines as long as the teaching and learning strategies and materials meet the expectations of the curriculum. In other words, teachers and school professional staff can design their own materials and assignments based on the levels and standards of their students. All the participants mentioned the flexibilities and arrangements multiple times as they believed this is one of the most important factors during their teaching career development. For example, one said, "for my standard students, I design group activities...for advanced level students, individual activities can be appropriate to challenge their skills..." (Teacher \#34, Mathematics, Beijing).

In summary, due to the nature of the teaching and educational profession (Weiner \& Jerome, 2016) many people do not enjoy the sense of isolation which occurs, since university education usually tends to engage in group activities and collective responsibilities for teaching and learning. Due to the nature of the teaching and educational profession, most of the responsibilities and arrangements tend to be self-arranged tasks without much interaction with colleagues. Therefore, a number of junior-level teachers and school professional staff decided to leave due to the sense of isolation (Boe, Cook, \& Sunderland, 2008). However, in this study, all of the second-career and career switching teachers and school professional staff enjoy the isolation, due to their personality. More importantly, all of them have gained professional and industrial experience from their previous career. All of them understood their interests, goals, and working behaviours before joining the teaching and educational professions (Lent... et al., 2000). Therefore, all of them enjoyed the nature of the profession and decided to stay in that working environment for more than ten years in mainland China.

\subsection{Well-Established Facilities}

A large number of participants also expressed that both hardware and software facilities in their schools and communities were excellent for teaching and learning activities in contemporary mainland China. Particularly for teachers and school professional staff who had previous teaching experience before joining their current international school in mainland China. Most of the teachers strongly believed the overall facilities helped them to deliver the materials appropriately. 


\subsubsection{Hardware}

Multiple teachers and school professional staff expressed that the Chinese government, families, parents and students strongly believe that science subjects can change and improve their current communities and society. Therefore, schools and government agencies always contribute resources and funding to upgrade their science facilities and materials. For example, all the participants' schools have at least two science labs and even a botanical garden for teaching and learning purposes. As a lab technician said, "all secondary students are required to come to the lab for biology, chemistry and physics classes at least three times per week...Chinese schools care about lab experiments and real interactions...this is hard to find in most South African schools..." (Lab Technician \#2, Lab, Beijing). Besides multiple sharing about the lab facilities, several participants also stated that their school has a botanical garden with a greenhouse. One participant stated that the greenhouse allowed the students to farm fruit and vegetables during the winter seasons, saying, "senior high school students can plant their fruit and vegetables, such as tomatoes, strawberries, cucumbers and sunflowers in the greenhouse...students can learn botanical knowledge in the urban environment..." (Teacher \#33, Biology, Beijing).

\subsubsection{Software}

Besides the hardware, more than half the participants said that their schools are currently using at least two types of learning platforms and Smartphone apps for teaching and learning purposes. Although internet access to specific websites may be limited, most of the teachers and school professional staff developed their own teaching and learning materials for their classrooms. First, multiple teachers and school professional staff expressed that their schools had purchased a cloud computing system which allowed students and staff to upload and download materials. One said "my students can upload their homework and I can download their homework for grading... although it is not a new technology, it is still a technical classroom..." (Teacher \#35, Spanish, Beijing).

Secondly, many teachers and school professional staff advocated that they can host online discussions during the evenings without geographic limitations. For example, when some students are leaving the city for a match or conference, all students and classmates can join the live chat in the evening for discussion, one participant said, "...once a group of five went to Thailand for a mathematics game...we could start the conference chat at 10 p.m. at night...we can share our ideas, homework and activities online...it is excellent..." (Teacher \#45, Mathematics, Shanghai).

In short, in recent decades, both local and international schools in mainland China have invested a significant number of resources into hardware and software development. Due to the development of instructional technology and technology-oriented classroom tools and facilities, smart Chinese classrooms are not hard to find in mainland China, particularly in urban classrooms and schools. Therefore, due to the smart classroom environment, the workload and preparation which teachers have to do may be reduced, as many assignments and worksheets can be done via computer and learning devices. Also, interactive hardware such as garden and science labs increase the interests of both teachers and students. Without a doubt, contemporary Chinese classrooms always encourage the engagement and interaction of both teachers and students.

\section{Conclusion}

The current study will contribute to the field of international schooling, human resource management of schools, school recruitment, teachers' turnover and retention and teachers' professional development by exploring why international school teachers decide to stay and invest their career development in a particular international school in mainland China. Although this research focused on the result from two Chinese metropolitans, the findings could reflect other similar regions in the East Asian environment and expand the knowledge of international schooling, as well as inform the problem in the retention of teachers.

This research has a number of recommendations. All schools face significant problems with teacher turnover. However, school administrators need to figure out the long-term solution, particularly for international schools where turnover could be much more costly than local schools in home nations. Experienced international school teachers and school professional staff have expressed their recommendations about "acknowledgement from upper leadership", "classroom/workplace authorities", and "well-established facilities" as potential solutions. School administrators can pay attention and focus on these areas for teacher professional development and school managerial improvement in order to attract both junior and senior-level teachers internationally.

For future research direction, there are three potential recommendations. First, this research will continue to explore other urban cities and regions in the East Asian region. Although the large populations in Beijing and Shanghai may represent the overall situation in mainland China, other large cities and regions, such as Guangzhou, Tianjin and Shenzhen may face different challenges and difficulties since China is one of the biggest countries on earth. Therefore, exploring additional cities and regions may help school administrators to solve problems and difficulties. Second, future research may explore the problems and difficulties of foreign teachers and school professional staff who are teaching at one of the local schools in mainland China. In fact, international schools may establish and invest a significant number of facilities and programmes for foreign teachers and students to overcome cultural and social differences. However, local schools may not have such resources for investment. Therefore, future research studies may cover these factors.

\section{References}

Al Salami, M. K., Makela, C. J., \& de Miranda, M. A. (2017). Assessing changes in teachers' attitudes toward interdisciplinary STEM teaching. International Journal of Technology and Design Education, 27(1), 63-88. Available at: https://doi.org/10.1007/s 10798-0159341-0.

Bandura, A. (1995). Self-efficacy in changing societies. Cambridge, UK: Cambridge University Press.

Bandura., A. (1989). Perceive self efficacy in the exercise agency: The psychologist. Bulletin of the British Psychological Society, 10, $411-424$.

Boe, E. E., Cook, L. H., \& Sunderland, R. J. (2008). Teacher turnover: Examining exit attrition, teaching area transfer, and school migration. Exceptional Children, 75(1), 7-31. Available at: https://doi.org/10.1177/001440290807500101. 
Brouwers, A., \& Tomic, W. (2000). A longitudinal study of teacher burnout and perceived self-efficacy in classroom management. Teaching and Teacher Education, 16(2), 239-253. Available at: https://doi.org/10.1016/S0742-051X(99)00057-8.

Bubbar, K., Dimopolous, A., Gaetz, R., Wild, P., \& McWilliam, M. (2017). Evolution of the design engineering mentorship program. Paper presented at the Proceedings of the Canadian Engineering Education Association (CEEA).

Chambers, D. (2002). The real world and the classroom: Second-career teachers. The Clearing House, 75(4), 212-217. Available at: https://doi.org/10.1080/00098650209604935.

Chandler, J. (2010). The role of location in the recruitment and retention of teachers in international schools. Journal of Research in International Education, 9(3), 214-226. Available at: https://doi.org/10.1177/1475240910383917.

Clandnin, D., \& Connelly, F. (2000). Narrative inquiry: Experience and story in qualitative research. San Francisco, CA: Jossey-Bass.

Connell, F., \& Clandinia, D. (1990). Stories of experience and narrative inquiry. Educational Researcher, 19(5), 2-14. Available at: https://doi.org/10.3102/0013189x019005002.

Creswell, J. (2012). Qualitative inquiry and research design: Choosing among five approaches. Thousand Oaks, CA: Sage.

Dicke, T., Elling, J., Schmeck, A., \& Leutner, D. (2015). Reducing reality shock: The effects of classroom management skills training on beginning teachers. Teaching and Teacher Education, 48, 1-12. Available at: https://doi.org/10.1016/j.tate.2015.01.013.

Dos Santos, L. M. (2016). Relationship between turnover rate and job satisfaction of foreign language teachers in Macau. Journal of Educational and Developmental Psychology, 6(2), 125.

Dos Santos, L. M. (2019a). Engineering education as a second career: The experience of female practising engineers. Global Journal of Engineering Education, 21(3), 202-207.

Dos Santos, L. M. (2019c). Pre-service teachers' professional development through four-step problem-solving model: A seminar method. International Journal of Education and Practice, 7(3), 146-157. Available at: https://doi.org/10.18488/journal.61.2019.73.146.157.

Dos Santos, L. M. (2019d). Recruitment and retention of international school teachers in remote archipelagic countries: The Fiji experience. Education Sciences, 9(2), 132.

Guarino, C. M., Santibanez, L., \& Daley, G. A. (2006). Teacher recruitment and retention: A review of the recent empirical literature. Review of Educational Research, 76(2), 173-208. Available at: https://doi.org/10.3102/00346543076002173.

Hardman, J. (2001). Improving recruitment and retention of quality overseas teachers. In S. Blandford \& M. Shaw (Eds.), Managing International Schools (pp. 123-135). London, UK: Routledge Falmer.

Hayden, M. (2006). Introduction to international education: International schools and their communities. London, UK: Sage.

Hayden, M., \& Thompson, J. (2008). International schools: Growth and influence. Paris, France: UNESCO.

Ingersoll, R. M. (2001). Teacher turnover and teacher shortages: An organizational analysis. American Educational Research Journal, 38(3), 499-534. Available at: https://doi.org/10.3102/00028312038003499.

Ingersoll, R. M. (2003). Who controls teachers' work? Power and accountability in America's schools. Cambridge, MA: Harvard University Press.

Ingersoll., R. M., \& Smith, T. M. (2003). The wrong solution to the teacher shortage. Educational Leadership, 60(8), 30-33.

Lent, R. W., Brown, S. D., \& Hackett, G. (1994). Toward a unifying social cognitive theory of career and academic interest, choice, and performance. Journal of Vocational Behavior, 45(1), 79-122. Available at: https://doi.org/10.1006/jvbe.1994.1027.

Lent., R. W., Brown, S. D., Brenner, B., Chopra, S. B., Davis, T., Talleyrand, R., \& Suthakaran, V. (2001). The role of contextual supports and barriers in the choice of math/science educational options: A test of social cognitive hypotheses. Journal of Counseling Psychology, 48(4), 474-483. Available at: https://doi.org/10.1037/0022-0167.48.4.474

Lent.., R. W., \& Brown, S. D. (1996). Social cognitive approach to career development: An overview. The Career Development Quarterly, 44(4), 310-32 1. Available at: https://doi.org/10.1002/j.2161-0045.1996.tb00448.x.

Lent..., R. W., Brown, S. D., \& Hackett, G. (2000). Contextual supports and barriers to career choice: A social cognitive analysis. Journal of Counseling Psychology, 47(1), 36-49. Available at: https://doi.org/10.1037/0022-0167.47.1.36.

Merriam, S. B. (2009). Qualitative research: A guide to design and implementation. San Francisco, CA: Jossey Bass.

Odland, G., \& Ruzicka, M. (2009). An investigation into teacher turnover in international schools. Journal of Research in International Education, 8(1), 5-29. Available at: https://doi.org/10.1177/1475240908100679.

Reinhold, S., Holzberger, D., \& Seidel, T. (2018). Encouraging a career in science: A research review of secondary schools' effects on students' STEM orientation. Studies in Science Education, 54(1), 69-103. Available at: https://doi.org/10.1080/03057267.2018.1442900.

Ronfeldt, M., Loeb, S., \& Wyckoff, J. (2013). How teacher turnover harms student achievement. American Educational Research Journal, 5o(1), 4-36. Available at: https://doi.org/10.3102/0002831212463813.

Seidman, I. (2013). Interviewing as qualitative research: A guide for researchers in education and the social sciences (4th ed.). New York: Teachers College Press.

Strauss, A., \& Corbin, J. M. (1990). Basics of qualitative research: Grounded theory procedures and techniques. Thousand Oaks, CA: Sage.

Tang, K. H., \& Dos Santos, L. M. (2017). A brief discussion and application of interpretative phenomenological analysis in the field of health science and public health. International Journal of Learning and Development, 7(3), 123-132. Available at: https://doi.org/10.5296/ijld.v7i3.11494.

Thomas, D. R. (2006). A general inductive approach for analyzing qualitative evaluation data. American Journal of Evaluation, 27(2), $237-246$. Available at: https://doi.org/10.1177/10982 14005283748.

Weiner, L. (2012). The future of our schools: Teachers unions and social justice. Chicago, IL: Haymarket Books.

Weiner, L., \& Jerome, D. (2016). Urban teaching: The essentials (3rd ed.). New York: Teachers College Press.

Zeidler, D. L. (2016). STEM education: A deficit framework for the twenty first century? A sociocultural socioscientific response. Cultural Studies of Science Education, 11(1), 11-26. Available at: https://doi.org/10.1007/s1 1422-014-9578-z. 